\title{
sciendo
}

\section{HERMETIA ILLUCENS FAT AFFECTS THE GASTROINTESTINAL TRACT SELECTED MICROBIAL POPULATIONS, THEIR ACTIVITY, AND THE IMMUNE STATUS OF BROILER CHICKENS}

\author{
Bartosz Kierończyk ${ }^{1}$, Mateusz Rawski², Zuzanna Mikołajczak ${ }^{1}$, Natalia Leciejewska³ ${ }^{3}$ Damian Józefiak ${ }^{1 \bullet}$ \\ ${ }^{1}$ Department of Animal Nutrition, Poznań University of Life Sciences, Wołyńska 33, 60-637 Poznań, Poland \\ ${ }^{2}$ Department of Zoology, Laboratory of Inland Fisheries and Aquaculture, Poznań University of Life Sciences, Wojska Polskiego 71C, \\ 60-625 Poznań, Poland \\ ${ }^{3}$ Department of Animal Physiology, Biochemistry, and Biostructure, Poznań University of Life Sciences, Wołyńska 35, 60-637 Poznań, Poland \\ •Corresponding author: damian.jozefiak@up.poznan.pl
}

\begin{abstract}
The present study investigated the effect of Hermetia illucens larvae (BSFL) fat, derived using supercritical $\mathrm{CO}_{2}$ extraction and added to broiler chickens' diets as a partial (50\%) or total replacement for commonly used soybean oil, on the gastrointestinal tract (GIT) microbial population, its activity, and selected physiological and immune traits. A total of 576 one-day-old female Ross 308 chicks were randomly assigned to 3 dietary treatments with 16 replicates each. The following treatments were applied: SO - 100\% soybean oil, BSFL50 a mixture of BSFL and soybean oils in a 50:50 ratio, and BSFL100 - 100\% BSFL fat. Digesta samples from the crop, jejunum and caeca were collected for further analyses, i.e., $\mathrm{pH}$ measurements, fluorescent in situ hybridization, and short-chain fatty acid (SCFA) concentrations. Additionally, the selected plasma biochemical parameters and immunological traits were assessed. In general, the implementation of BSFL fat in broilers' diets resulted in increased proliferation of potentially pathogenic bacterial populations in the crop, such as Enterobacteriaceae, Bacteroides-Prevotella cluster, and Clostridium perfringens. Furthermore, BSFL100 enhanced microbial activity via total SCFA production and lowered the $\mathrm{pH}$ in this segment. However, no detrimental effects were observed in terms of other GIT segments, i.e., the jejunal and cecal microecosystems. The strongest impact on reduction of select components of the microbial population in the cecum was observed with the BSFL50 treatment for potentially pathogenic bacteria such as Enterobacteriaceae, Bacteroides-Prevotella cluster, while commensal populations were also limited, i.e., Bacillus spp., C. leptum subgroup, and C. coccoides-Eubacterium rectale cluster. Additionally, BSFL100 reduced the cholesterol concentration in the blood, while both experimental treatments decreased the ALT level. In conclusion, due to the insufficient release of lauric acid from the BSFL fat in the crop, an adverse shift in the microbiota can be noted. However, a positive suppressive effect on the select components of the cecal microbiota, as well as improvement of liver health suggests implying the BSFL fat in broiler nutrition.
\end{abstract}

Key words: black soldier fly, alternative dietary energy fat, microbiota, microbial activity, immune status

Hermetia illucens larvae (black soldier fly larvae, BSFL), which are substantial carriers of dietary fat reaching approximately 30-45\% (in dry matter, DM) (Feng et al., 2019), are considered a sustainable and innovative feed material that could be used in livestock nutrition, including poultry (Benzertiha et al., 2020). Currently, insect fat is primarily administered to animal diets as a substituent of environmentally harmful or genetically modified (GM) and commonly used feed materials, such as soybean, palm, coconut, and corn oils, as well as poultry fat (Kierończyk et al., 2018; Benzertiha et al., 2019; Kim et al., 2020 b). From a practical point of view, only the fat fraction from insect biomass can be used in livestock nutrition due to European Union restrictions (regulations no. 999/2001 and 1069/2009), except for live insects, which can also be provided in animal diets. To date, only a small number of experiments have been performed to evaluate the effects of BSFL fat on the growth performance, nutrient digestibility coefficients, and select physiological traits of broilers (Kierończyk et al., 2020; Schiavone et al., 2017, 2018), laying hens (Heuel et al., 2021), and turkeys (Sypniewski et al., 2020). These studies indicated that there is no limiting factor that could negatively trigger the results of bird production parameters. Furthermore, there is evidence that BSFL fat may positively modulate physiological and immunological status through a high concentration of medium-chain fatty acids (MCFAs), including lauric acid (C12:0) as

*This work was supported by several sources, i.e., "IN OIL project: An innovative method for bioconversion of byproducts from food processing industry", which was financed by the National Centre for Research and Development within the Lider VII Program No. LIDER/5/0148/L-7/15/ NCBR/2016; and statutory funding no. 506.533.04.00 for the Faculty of Veterinary Medicine and Animal Science, Poznań University of Life Sciences, Poland, the Department of Animal Nutrition. 
a dominant component (Sypniewski et al., 2020). BSFL, as the most profitable species due to flexibility in terms of adaptation to the rearing substrate (preconsumer wastes), favorable nutritive value, and short-term production, has the highest economic potential for usage in animal diets (Józefiak et al., 2016 a). Nevertheless, the larval nutritive value, short-chain fatty acid (SCFA) profile, MCFA concentration, and lauric acid level are notably dependent on the growth performance, especially larval weight (Ewald et al., 2020), rearing substrate composition (BarraganFonseca et al., 2019; Kierończyk et al., 2020), processing of insect biomass, e.g., slaughter (Caligiani et al., 2019), freezing, and drying methods (Melis et al., 2018), as well as the refining of fat (Mai et al., 2019). It is well documented that MCFAs have a notable influence on the growth performance and gastrointestinal tract (GIT) microbial homeostasis of broiler chickens (Hejdysz et al., 2018; Baltić et al., 2017, 2018). In particular, lauric acid (C12:0) and its monoglyceride, i.e., monolaurin, exert antimicrobial, antiviral, and antiparasitic properties by disrupting the bacterial cell membrane (Lieberman et al., 2006; Kim and Rhee, 2016). Therefore, due to the nonunified large scale BSFL production, various processing techniques, and unknown nutrient requirements for sixlegged livestock, there is a risk of limiting the beneficial role of BSFL fat, particularly via reduction of lauric acid (C12:0) concentration even by nearly $40 \%$, and consequently the possible occurrence of adverse microbiota modulation of the GIT (Kierończyk et al., 2020; Ewald et al., 2020). Thus, it is crucial to evaluate the systemic effects of the process extending from BSFL production to the response of poultry to diet, in which invertebrate fat, i.e., as energy source, is included as a replacement. To date, only Sypniewski et al. (2020) have shown the effect of BSFL fat on the jejunal microbiota, where Enterobacteriaceae was significantly limited. There is a lack of information in the available literature about the influence of this novel energy source on microbiota populations throughout the entire GIT, which could have an impact on bird health status. Therefore, the current study investigated the effect of BSFL fat, derived using supercritical $\mathrm{CO}_{2}$ extraction added to broiler chicken diets as a partial $(50 \%)$ or total replacement for commonly used soybean oil, on the GIT microecosystem, microbial activity, and immune status.

\section{Material and methods}

\section{Ethics statement}

According to Polish law and EU directive (no 2010/63/ EU), the experiments conducted within the study do not require the approval of the Local Ethical Committee for Experiments on Animals in Poznań (Poland).

\section{Birds and housing}

The current study is a continuation of a previously published experiment conducted on broiler chickens
(Kierończyk et al., 2020). Due to the previously obtained growth performance and nutrient digestibility coefficient results, which indicated the possibility of soybean oil replacement by BSFL fat at each level, i.e., 25, 50, 75, and $100 \%$, the authors employed three major treatments to proceed with microbial analyses. In total, 576 oneday-old female Ross 308 chicks obtained from a commercial hatchery were randomly allotted (completely randomized design) to 3 dietary treatments. Each group had 16 replicates and 12 birds per replicate. The broilers were kept in 48 floor pens $(1 \mathrm{~m} \times 1 \mathrm{~m})$ over $35 \mathrm{~d}$, with fresh wheat straw used as litter. The pens were set up in the center of a commercial chicken house. To imitate the intensive broiler chicken rearing conditions, the experimental pens were surrounded by a commercial bird flock of 9,000 specimens of the same origin as those used in the experiments. The building was equipped with artificial, programmable fluorescent lights, automatic electric heating, and forced ventilation, which were arranged according to the recommendations of the Management Handbook (Aviagen, 2018). The lighting program was set up based on endorsements of the Council Directive (2007/43/EC). The temperature inside the building was set up at $32-33^{\circ} \mathrm{C}$ at the beginning of the test and was reduced by $2-3^{\circ} \mathrm{C}$ each week. On the 28 th day, the temperature was set at $21^{\circ} \mathrm{C}$ and was approximately $18^{\circ} \mathrm{C}$ at the end of the test.

\section{Insect fat composition}

Two dietary fats, i.e., SO and BSFL fat, were purchased from commercial sources - Piast Pasze Sp. z o.o., and HiProMine S. A (Poland). The BSFL was grown on a vegetable substrate, i.e., carrots, potatoes, and cabbage, as previously described (Kierończyk et al., 2020), without any contamination by animal origin products based on EC regulation (no 1069/09). The dry matter (DM) of the rearing medium was fixed at the $22 \%$ level. Based on Weththasinghe et al. (2021), the substrate before feeding was ground $(2000 \mathrm{rpm} / 1 \mathrm{~min}$, [HiProMine milling system], $55 \mathrm{~kW}$, Poland) to pass through a 2-mm screen. The feed was provided ad libitum without supplementation of additional technical water. The larvae at the prepupal stage were gathered on the 10th day of rearing. Next, the larvae were sieved (3-mm screen) and washed (drum separator under the following conditions: $90^{\circ} \mathrm{C}$ per 10 min (HiProMine cleaning system, Poland). During the production process, the temperature and humidity were controlled at $28^{\circ} \mathrm{C}$ and $70 \%$, respectively. Dietary BSFL fat was obtained using supercritical $\mathrm{CO}_{2}$ extraction according to Jackowski et al. (2015). Supercritical $\mathrm{CO}_{2}$ extraction is frequently used to obtain invertebrate fat and is recommended due to the waiver of organic solvents and implementation of low temperatures (Purschke et al., 2017). Before extraction, the material was air-dried in an oven (SLN 240, POL-EKO Aparatura, Poland) for $24 \mathrm{~h}$ at $50^{\circ} \mathrm{C}$. The following parameters were used for the extraction: pressure $-300 \mathrm{bar}$, temperature $-40^{\circ} \mathrm{C}$. For extract collection, a two-separator system was used. 
The $\mathrm{CO}_{2}$ flow was adjusted to $110.4 \mathrm{~kg} / \mathrm{h}$. Commercial $\mathrm{CO}_{2}$ (99\% purity, Zakłady Azotowe, Puławy, Poland) was used for the extraction. The fatty acid composition of these fats was presented previously in Kierończyk et al. (2020).

Table 1. Composition and nutritive value of experimental diets (Kierończyk et al., 2020*)

\begin{tabular}{|c|c|c|}
\hline Ingredient $\left(\mathrm{g} \mathrm{kg}^{-1}\right)$ & $1-14 d$ & $14-35 d$ \\
\hline Maize & 560.0 & 634.1 \\
\hline Soybean meal & 364.3 & 285.7 \\
\hline Soybean oil/Hermetia illucens fat & 33.4 & 49.2 \\
\hline Dicalcium phosphate & 26.1 & 11.9 \\
\hline Mineral-vitamin premix ${ }^{\mathrm{a}}$ & 3.0 & 3.0 \\
\hline Limestone & 2.3 & 5.9 \\
\hline Salt $(\mathrm{NaCl})$ & 2.7 & 2.5 \\
\hline Sodium sulfate $\left(\mathrm{Na}_{2} \mathrm{SO}_{4}\right)$ & 1.4 & 1.1 \\
\hline L-Lysine & 2.1 & 2.2 \\
\hline DL-Methionine & 2.8 & 2.5 \\
\hline Tryptophane & 0.5 & \\
\hline L-Threonine & 1.0 & 1.6 \\
\hline L-Valine & 0.4 & 0.4 \\
\hline Titanium dioxide $\left(\mathrm{TiO}_{2}\right)$ & & 2.0 \\
\hline \multicolumn{3}{|l|}{ Analyzed nutritive value $\left(\mathrm{g} \mathrm{kg}^{-1}\right)$} \\
\hline $\mathrm{ME}\left(\mathrm{MJ} \mathrm{kg}^{-1}\right)$ & 12.6 & 13.4 \\
\hline Crude protein & 215.8 & 185.0 \\
\hline Ether extract & 59.4 & 76.7 \\
\hline Crude fiber & 26.5 & 25.1 \\
\hline $\mathrm{Ca}$ & 8.5 & 6.5 \\
\hline Lysine & 13.1 & 11.2 \\
\hline Methionine + cysteine & 9.7 & 8.6 \\
\hline
\end{tabular}

a Provided the following per kilogram of diet: vitamin A, $11.166 \mathrm{IU}$; cholecalciferol, $2500 \mathrm{IU}$; vitamin E, $80 \mathrm{mg}$; menadione, $2.50 \mathrm{mg}$; vitamin $\mathrm{B}_{12}, 0.02 \mathrm{mg}$; folic acid, $1.2 \mathrm{mg}$; choline, $379 \mathrm{mg}$; D-pantothenic acid, 12.5 $\mathrm{mg}$; riboflavin, $7.0 \mathrm{mg}$; niacin, $41.7 \mathrm{mg}$; thiamine, $2.2 \mathrm{mg}$; biotin, $0.18 \mathrm{mg}$; pyridoxine, $4.0 \mathrm{mg}$; ethoxyquin, $0.09 \mathrm{mg}$; $\mathrm{Mn}\left(\mathrm{MnO}_{2}\right), 73 \mathrm{mg} ; \mathrm{Zn}(\mathrm{ZnO})$, $55 \mathrm{mg}$; $\mathrm{Fe}\left(\mathrm{FeSO}_{4}\right), 45 \mathrm{mg} ; \mathrm{Cu}\left(\mathrm{CuSO}_{4}\right), 20 \mathrm{mg}$; I $\left(\mathrm{CaI}_{2} \mathrm{O}_{6}\right), 0.6 \mathrm{mg}$; and $\mathrm{Se}$ $\left(\mathrm{Na}_{2} \mathrm{SeO}_{3}\right), 0.3 \mathrm{mg}$.

*The presented data are a continuation of the same experiment, which has partially been published as a part of the same project table with the composition of the diets adopted from Kierończyk et al. (2020).

\section{Broiler diets}

The composition of the broiler basal diet is shown in Table 1. Birds had ad libitum access to water and feed for $35 \mathrm{~d}$ ( 2 nipple drinkers and 1 feed hopper per pen). For each feeding period, all diets were calculated to meet or exceed the nutrient requirements recommended by the NRC (1994) for broiler chickens. The diets were formulated to remain isonitrogenous and isoenergetic. It should be highlighted that due to the lack of the apparent metabolizable energy corrected to zero nitrogen balance $\left(\mathrm{AME}_{\mathrm{N}}\right)$ value for BSFL fat in the available literature, the authors decided to define its energetic value similar to that of SO based on previously conducted experiments evaluating the growth performance results (Kierończyk et al., 2020; Sypniewski et al., 2020). The composition of the basal diet was designed according to Tancharoenrat et al. (2013) and was formulated based on maize and soybean meal. The diets were prepared in mash form; all of the raw materials were ground by a disc mill (Skiold A/S, Denmark) at a $2.5 \mathrm{~mm}$ disc distance and mixed without heat treatment. The feed was produced in the Piast Pasze feed mill (Lewkowiec, Poland) according to ISO 9001:2008 procedures. The feed was prepared on a laboratory-scale line equipped with a horizontal double band mixer (Zuptor, Gostyń, Poland) with roller mills (Skiold, Sæby, Denmark). Starter diets were offered to all birds from 1 to $14 \mathrm{~d}$ of age, and grower-finisher diets were offered from 15 to $35 \mathrm{~d}$ of age. No exogenous enzymes, such as carbohydrases, proteases, and phytases, were used in the study. Furthermore, no ionophore coccidiostat was added to the feed. The following treatments were applied: SO - 100\% soybean oil, BSFL50 - a mixture of BSFL and soybean oils in a 50:50 ratio, BSFL100 $-100 \%$ BSFL fat.

\section{Data and sample collection}

The digesta samples from the crop, jejunum and caeca were gently squeezed into segments from 16 individual birds (1 randomly chosen broiler per pen, i.e., replication). The jejunum was defined as a segment beginning at the end of the duodenum and ending at Meckel's diverticulum. The $\mathrm{pH}$ value in the selected GIT segments was determined using a combined glass and reference electrode (VWR International, pH 1000 L, Leuven, Belgium) directly after slaughter (1 randomly chosen bird per pen, $n=16)$. The remaining crop, jejunal, and cecal contents were immediately frozen in flexigrip bags and stored at $-80^{\circ} \mathrm{C}$ for further analyses using the molecular microbiology method, i.e., fluorescent in situ hybridization (FISH) of single bacterial cells. Furthermore, gas chromatography (GC) was used to obtain the microbial activity results, i.e., short-chain fatty acid (SCFA) concentrations.

\section{The selected plasma parameters}

Blood samples were collected postmortem after decapitation from 1 individual bird per replication pen (randomly chosen, $\mathrm{n}=16$ ). Furthermore, plasma was obtained by centrifugation using a Micro 220R (Hettich, Tuttlingen, Germany) under the following conditions: $1,000 \times g$ at $8^{\circ} \mathrm{C}$ for $10 \mathrm{~min}$ and stored at $-20^{\circ} \mathrm{C}$ until analysis. Based on Kierończyk et al. (2017), selected parameters were determined (in duplicate), including the concentration of glucose, triglycerides (TG), nonesterified fatty acid (NEFA), total cholesterol, total protein, albumin, alanine aminotransferase (ALT), and aspartate aminotransferase (AST). Additionally, immunological traits, i.e., immunoglobulin $\mathrm{M}$ (IgM), immunoglobulin A (IgA), immunoglobulin G (IgG), interleukin-2 (IL-2), and interleukin-6 (IL-6) concentrations, were determined using species-specific commercially available ELISA kits (Shanghai Sunred Biological Technology Co., Ltd, Shanghai, China or Abnova Corporation, Taipei, Tai- 
wan). All analyses were performed according to the manufacturer's instructions.

\section{Microbial analyses}

All details of sample preparation and FISH analyses for bacterial enumeration from the crop, jejunal, and cecal digesta were described by Rawski et al. (2016) and Józefiak et al. (2013). Briefly, $100 \mu \mathrm{L}$ of the digesta (8 pooled replicates with 2 birds each, $n=8$ ) was diluted in PBS, pipetted onto $0.22-\mu \mathrm{m}$ polycarbonate filters (Frisenette K02BP02500) and vacuumed (Vaccum KNF VacuportNeuberg). After vacuuming, the filters were transferred onto cellulose discs for dehydration in an ethanol series (50, 80, and 96\%, 3 min each). For each sample, a series of identical filters was prepared to allow the determination of optimal hybridization. The oligonucleotide probes used for this study were selected from the literature and are listed in Table 2. Hybridizations were carried out in $50 \mu \mathrm{L}$ of hybridization buffer $(0.9 \mathrm{M} \mathrm{NaCl} ; 20 \mathrm{mM}$ Tris/ $\mathrm{HCl}, \mathrm{pH} 7.2 ; 0.01 \%$ SDS) containing the oligonucleotide probes. After hybridization, the filters were washed with washing buffer $(20 \mathrm{mM}$ Tris/ $\mathrm{HCl}, \mathrm{pH} 7.2 ; 0.01 \%$ SDS; $5 \mathrm{mM}$ EDTA) for $20 \mathrm{~min}$ at $48^{\circ} \mathrm{C}$. The filters were rinsed gently in distilled water, air-dried, and mounted on object glasses with VectaShield (Vector Laboratories nr. H-1000) anti-fading agent containing DAPI (4',6-diamidino-2-phenylindole). To distinguish the total count of bacteria (DAPI) from other particles in the digesta samples, filters were left at $4^{\circ} \mathrm{C}$ for one hour in the dark until visualized using an Axio Imager M2 microscope (Carl Zeiss, Jena, Germany).

The SCFA concentrations in the digesta ( 8 pooled replicates with 2 birds each, $n=8$ ) of the selected GIT locations were determined according to Canibe et al. (2007). Briefly, digesta samples were subjected to analysis using GC (Shimadzu GC-2010, Kyoto, Japan). The samples $(0.5 \mathrm{~g}$ crop and jejunal samples, $0.2 \mathrm{~g}$ cecal samples) were mixed with $0.2 \mathrm{ml}$ of formic acid, diluted with deionized water, and centrifuged at $7,211 \times g$ for 10 min. The supernatant was loaded onto a capillary column (SGE BP21, $30 \mathrm{~m} \times 0.53 \mathrm{~mm}$ ) using an on-column in- jector. The initial oven temperature was $85^{\circ} \mathrm{C}$ and was raised to $180^{\circ} \mathrm{C}$ by $8^{\circ} \mathrm{C} / \mathrm{min}$ and held there for $3 \mathrm{~min}$. The temperatures of the flame ionization detector and the injection port were set at $180^{\circ} \mathrm{C}$ and $85^{\circ} \mathrm{C}$, respectively. The sample volume used for GC analysis was $1 \mu$ l. The putrefactive SCFA (PSCFA) concentration was calculated as the sum of iso-butyrate $(\mathrm{C} 4 \mathrm{i})$, iso-valerate $(\mathrm{C} 5 \mathrm{i})$, and valerate $(\mathrm{C} 5)$ concentrations in the digesta.

\section{Statistical analysis}

The conducted experiment was set up using a completely randomized design. The experimental unit was defined as a randomly chosen bird $(n=16)$ in terms of $\mathrm{pH}$ value, as well as selected plasma parameters. For microbial analyses due to the relatively small amount of the digesta, the samples had been pooled with two birds $(n=8)$. The Shapiro-Wilk test was used to determine normal distribution. Bartlett's test was adopted to evaluate the homogeneity of variance. Duncan's multiple range post hoc test was used to determine the significance of differences between treatment means at the significance level of $\mathrm{P}<0.05$. Due to the occurrence of nonnormally distributed data, Dunn's test with Benjamini-Hochberg adjustment for multiple comparisons followed by a significant Kruskal-Wallis test was used. The analyses were performed via RStudio (v. 1.2.5033; 2009-2019 RStudio, Inc., Boston, USA) using the stats (v. 3.6.2) (Schumacker and Tomek, 2013), agricolae (v. 1.3-3) (De Mendiburu and Simon, 2015), psych (v. 2.0.12) (Revelle, 2017), dplyr (v. 1.0.2) (Mailund, 2019), FSA (v. 0.8.31) (Ogle, 2016), and rcompanion (v. 2.3.26) (Rasco, 2020) packages. The following model was applied:

$$
Y_{i}=\mu+\alpha_{i}+\delta_{i j}
$$

where:

$Y_{i}$ is the observed dependent variable,

$\mu$ is the overall mean,

$\alpha_{i}$ is the effect of a dietary fat source,

$\delta_{i j}$ is the random error.

Table 2. Selected oligonucleotide probes used in the study

\begin{tabular}{|c|c|c|c|}
\hline Target & Probe & Sequence $\left(5^{\prime}-3^{\prime}\right)$ & References \\
\hline Bacteroides-Prevotella cluster & Bacto303 & CCA ATG TGG GGG ACC TT & Manz et al. (1993) \\
\hline Clostridium leptum subgroup & Clept1240 & GTT TTR TCA ACG GCA GTC & Sghir et al. (2000) \\
\hline Clostridium perfringens & Cpref191 & GTA GTA AGT TGG TTT CCT CG & Fallani et al. (2006) \\
\hline Enterobacteriaceae & Enter1432 & CTT TTG CAA CCC ACT & Sghir et al. (2000) \\
\hline Clostridium coccoides-Eubacterium rectale cluster & Erec482 & GCT TCT TAG TCA RGT ACC G & Franks et al. (1998) \\
\hline Lactobacillus group & Lab722 & YCA CCG CTA CAC ATG RAG TTC CAC T & Sghir et al. (2000) \\
\hline Bacillus spp. & Bmy 843 & CTT CAG CAC TCA GGT TCG & Salzman et al. (2002) \\
\hline
\end{tabular}




\section{Results}

\section{Microbiota composition}

The effect of BSFL fat inclusion in broiler chicken diets on the crop digesta microecosystem is shown in Table 3. In general, the total replacement of SO by BSFL fat resulted in increased proliferation of the total number of bacteria $(\mathrm{P}=0.005)$, Clostridium leptum subgroup $(\mathrm{P}<0.001)$, Enterobacteriaceae $(\mathrm{P}=0.016)$, and Lactobacillus group $(\mathrm{P}=0.019)$ in comparison to the control treatment and BSFL50. Both partial and total replacement of SO enhanced the growth of the Bacteroides-Prevotella cluster $(\mathrm{P}=0.009)$. The Clostridium perfringens counts $(\mathrm{P}=0.034)$ were the highest in the BSFL50 group, while BSFL100 did not differ between treatments. BSFL fat did not influence the Clostridium coccoides-Eubacterium rectale cluster $(\mathrm{P}=0.282)$, and
Bacillus spp. $(\mathrm{P}=0.914)$ populations. No effect $(\mathrm{P}>0.05)$ of BSFL fat administration to the broiler diets was observed in each select microbial population in the jejunum (Table 4). In contrast, the microbial composition of the cecal content was affected mainly by partial substitution (Table 5). BSFL50 increased the total number of bacterial counts $(\mathrm{P}<0.001)$, whereas Enterobacteriaceae and Bacillus spp. counts were lower $(\mathrm{P}<0.05)$ than those in the SO and BSFL100 treatments. The Bacteroides-Prevotella cluster, Clostridium leptum subgroup, and Clostridium coccoides-Eubacterium rectale cluster were decreased $(\mathrm{P}<0.05)$ by BSFL50, in contrast to SO and BSFL100. Additionally, the experimental treatments did not differ from the control groups in terms of the Clostridium perfringens and Lactobacillus groups; however, the lowest counts were observed in the BSFL50 group $(\mathrm{P}=0.004$ and $\mathrm{P}=0.017$, respectively).

Table 3. Effect of partial or total replacement of soybean oil (SO) by black soldier fly larvae (BSFL) fat on selected microbiota populations (log $\mathrm{cfu} / \mathrm{ml}$ digesta) in the crop digesta in broiler chickens, determined by DAPI staining and fluorescence in situ hybridization (FISH)

\begin{tabular}{|c|c|c|c|c|c|}
\hline & \multicolumn{3}{|c|}{ Treatment } & \multirow{2}{*}{$\mathrm{SEM}^{4}$} & \multirow{2}{*}{ P-value } \\
\hline & $\mathrm{SO}^{1}$ & BSFL $50^{2}$ & BSFL $100^{3}$ & & \\
\hline \multicolumn{6}{|c|}{ Crop } \\
\hline $\mathrm{DAPI}^{5}$ & $8.19 \mathrm{~b}$ & $8.21 \mathrm{~b}$ & $8.48 \mathrm{a}$ & 0.039 & 0.005 \\
\hline Bacteroides-Prevotella cluster & $8.13 \mathrm{~b}$ & $8.38 \mathrm{a}$ & $8.34 \mathrm{a}$ & 0.034 & 0.009 \\
\hline Clostridium leptum subgroup & $8.06 \mathrm{~b}$ & $8.02 \mathrm{~b}$ & $8.32 \mathrm{a}$ & 0.043 & $<0.001$ \\
\hline Enterobacteriaceae & $8.14 \mathrm{~b}$ & $8.00 \mathrm{~b}$ & $8.39 \mathrm{a}$ & 0.044 & 0.016 \\
\hline Clostridium coccoides-Eubacterium rectale cluster & 8.29 & 8.38 & 8.39 & 0.026 & 0.282 \\
\hline Clostridium perfringens & $8.39 \mathrm{~b}$ & $8.53 \mathrm{a}$ & $8.40 \mathrm{ab}$ & 0.026 & 0.034 \\
\hline Bacillus spp. & 8.33 & 8.33 & 8.30 & 0.038 & 0.914 \\
\hline Lactobacillus group & $8.92 \mathrm{~b}$ & $8.99 \mathrm{~b}$ & $9.36 \mathrm{a}$ & 0.086 & 0.019 \\
\hline
\end{tabular}

$\mathrm{a}, \mathrm{b}-$ means within a row with no common letters differ significantly $(\mathrm{P}<0.05)$.

${ }^{1} \mathrm{SO}-100 \%$ soybean oil. ${ }^{2} \mathrm{BSFL} 50$ - a mixture of BSFL fat and SO in a 50:50 ratio. ${ }^{3} \mathrm{BSFL} 100-100 \%$ BSFL fat. ${ }^{4} \mathrm{SEM}-$ standard error of the mean. ${ }^{5}$ DAPI - total number of bacteria determined by 4',6-diamidino-2-phenylindole staining. Means represent 8 pooled replicates with 2 birds each $(\mathrm{n}=8)$.

Table 4. Effect of partial or total replacement of soybean oil (SO) by black soldier fly larvae (BSFL) fat on selected microbiota populations (log $\mathrm{cfu} / \mathrm{ml}$ digesta) in the jejunal digesta in broiler chickens, determined by DAPI staining and fluorescence in situ hybridization (FISH)

\begin{tabular}{|c|c|c|c|c|c|}
\hline & \multicolumn{3}{|c|}{ Treatment } & \multirow{2}{*}{$\mathrm{SEM}^{4}$} & \multirow{2}{*}{ P-value } \\
\hline & $\mathrm{SO}^{1}$ & BSFL50² & BSFL $100^{3}$ & & \\
\hline \multicolumn{6}{|c|}{ Jejunum } \\
\hline $\mathrm{DAPI}^{5}$ & 8.85 & 8.79 & 8.92 & 0.054 & 0.581 \\
\hline Bacteroides-Prevotella cluster & 8.60 & 8.58 & 8.51 & 0.036 & 0.581 \\
\hline Clostridium leptum subgroup & 8.63 & 8.58 & 8.57 & 0.053 & 0.399 \\
\hline Enterobacteriaceae & 8.73 & 8.73 & 8.66 & 0.044 & 0.164 \\
\hline Clostridium coccoides-Eubacterium rectale cluster & 8.69 & 8.66 & 8.66 & 0.050 & 0.573 \\
\hline Clostridium perfringens & 8.62 & 8.72 & 8.59 & 0.056 & 0.141 \\
\hline Bacillus spp. & 8.78 & 8.67 & 8.66 & 0.053 & 0.085 \\
\hline Lactobacillus group & 8.63 & 8.59 & 8.64 & 0.041 & 0.935 \\
\hline
\end{tabular}

${ }^{1} \mathrm{SO}-100 \%$ soybean oil. ${ }^{2} \mathrm{BSFL} 50$ - a mixture of BSFL fat and SO in a 50:50 ratio. ${ }^{3}$ BSFL100 - 100\% BSFL fat. ${ }^{4} \mathrm{SEM}-$ standard error of the mean. ${ }^{5}$ DAPI - total number of bacteria determined by 4',6-diamidino-2-phenylindole staining. Means represent 8 pooled replicates with 2 birds each $(\mathrm{n}=8)$. 
Table 5. Effect of partial or total replacement of soybean oil (SO) by black soldier fly larvae (BSFL) fat on selected microbiota populations (log $\mathrm{cfu} / \mathrm{ml}$ digesta) in the cecal digesta in broiler chickens, determined by DAPI staining and fluorescence in situ hybridization (FISH)

\begin{tabular}{l|c|c|c|c|c}
\hline & \multicolumn{3}{|c|}{ Treatment } & \multirow{2}{*}{ SEM $^{4}$} & \multirow{2}{*}{ P-value } \\
\cline { 2 - 3 } & SO $^{1}$ & BSFL50 $^{2}$ & BSFL100 $^{3}$ & & \\
DAPI & Caeca & & & & \\
Bacteroides-Prevotella cluster & $10.4 \mathrm{~b}$ & $10.7 \mathrm{a}$ & $10.2 \mathrm{~b}$ & 0.051 & $<0.001$ \\
Clostridium leptum subgroup & $10.2 \mathrm{a}$ & $9.66 \mathrm{~b}$ & $10.2 \mathrm{ab}$ & 0.068 & 0.003 \\
Enterobacteriaceae & $10.2 \mathrm{a}$ & $9.55 \mathrm{~b}$ & $10.1 \mathrm{ab}$ & 0.072 & $<0.001$ \\
Clostridium coccoides-Eubacterium rectale cluster & $10.1 \mathrm{a}$ & $9.52 \mathrm{~b}$ & $10.1 \mathrm{a}$ & 0.079 & 0.022 \\
Clostridium perfringens & $10.2 \mathrm{a}$ & $9.71 \mathrm{~b}$ & $10.1 \mathrm{ab}$ & 0.057 & 0.018 \\
Bacillus spp. & $10.1 \mathrm{ab}$ & $9.63 \mathrm{~b}$ & $10.2 \mathrm{a}$ & 0.065 & 0.004 \\
Lactobacillus group & $10.2 \mathrm{a}$ & $9.53 \mathrm{~b}$ & $10.2 \mathrm{a}$ & 0.079 & 0.022 \\
\hline
\end{tabular}

$\mathrm{a}, \mathrm{b}-$ means within a row with no common letters differ significantly $(\mathrm{P}<0.05)$. ${ }^{1} \mathrm{SO}-100 \%$ soybean oil. ${ }^{2} \mathrm{BSFL} 50-\mathrm{a}$ mixture of BSFL fat and SO in a 50:50 ratio. ${ }^{3} \mathrm{BSFL} 100-100 \%$ BSFL fat. ${ }^{4} \mathrm{SEM}$ - standard error of the mean. ${ }^{5} \mathrm{DAPI}$ - total number of bacteria determined by 4',6-diamidino-2-phenylindole staining. Means represent 8 pooled replicates with 2 birds each $(n=8)$.

\section{Microbiota activity}

The substitution of SO by BSFL fat affected the $\mathrm{pH}$ value in the crop, as well as jejunal digesta (Table 6). In both segments, full replacement significantly decreased the $\mathrm{pH}$ value $(\mathrm{P}<0.05)$, while BSFL50 was characterized by intermediate results in the jejunum. The $\mathrm{pH}$ of the cecal content was not affected $(\mathrm{P}=0.415)$.

Table 6. Effect of partial or total replacement of soybean oil (SO) with black soldier fly larvae (BSFL) fat on selected GIT segment $\mathrm{pH}$ values in broiler chickens

\begin{tabular}{l|c|c|c|c|c}
\hline & \multicolumn{3}{|c|}{ Treatment } & \multirow{2}{*}{ SEM $^{4}$} & \multirow{2}{*}{ P-value } \\
\cline { 2 - 4 } & $\mathrm{SO}^{1}$ & BSFL50 $^{2}$ & BSFL100 $^{3}$ & & \\
\hline \multirow{5}{*}{ PH } \\
Crop & $4.90 \mathrm{a}$ & $5.14 \mathrm{a}$ & $4.48 \mathrm{~b}$ & 0.09 & 0.007 \\
Jejunum & $5.86 \mathrm{a}$ & $5.75 \mathrm{ab}$ & $5.56 \mathrm{~b}$ & 0.04 & 0.010 \\
Caeca & 6.38 & 6.44 & 6.32 & 0.05 & 0.415 \\
\hline
\end{tabular}

$\mathrm{a}, \mathrm{b}-$ means within a row with no common letters differ significantly $(\mathrm{P}<0.05) .{ }^{1} \mathrm{SO}-100 \%$ soybean oil. ${ }^{2} \mathrm{BSFL} 50$ - a mixture of BSFL fat and SO in a 50:50 ratio. ${ }^{3}$ BSFL $100-100 \%$ BSFL fat. ${ }^{4}$ SEM - standard error of the mean. Means represent 16 birds (1 randomly chosen chick per pen).

Table 7. Effect of partial or total replacement of soybean oil (SO) by black soldier fly larvae (BSFL) fat on volatile fatty acids ( $\mu \mathrm{mol} / \mathrm{g}$ digesta) and short-chain fatty acid profiles in the crop digesta in broiler chickens

\begin{tabular}{l|c|c|c|c|c}
\hline & \multicolumn{3}{|c|}{ Treatment } & \multirow{2}{*}{ SEM $^{4}$} & \multirow{2}{*}{ P-value } \\
\cline { 2 - 4 } & $\mathrm{SO}^{1}$ & BSFL50 & BSFL1003 & & \\
\hline 1 & 2 & 3 & 4 & 5 & 6 \\
\hline Acetic & $10.90 \mathrm{~b}$ & $10.50 \mathrm{~b}$ & $18.80 \mathrm{a}$ & 1.031 & 0.001 \\
Propionic & $0.14 \mathrm{ab}$ & $0.06 \mathrm{~b}$ & $0.27 \mathrm{a}$ & 0.034 & 0.027 \\
Iso-butyric & 0.02 & 0.04 & 0.05 & 0.012 & 0.443 \\
Butyric & $0.03 \mathrm{~b}$ & $0.04 \mathrm{ab}$ & $0.05 \mathrm{a}$ & 0.002 & 0.006 \\
Iso-valeric & $0.03 \mathrm{c}$ & $0.17 \mathrm{~b}$ & $0.26 \mathrm{a}$ & 0.018 & $<0.001$ \\
Valeric & 0.03 & 0.03 & 0.06 & 0.009 & 0.384 \\
\hline
\end{tabular}

Table 7 - contd.

\begin{tabular}{c|c|c|c|c|c}
\hline 1 & 2 & 3 & 4 & 5 & 6 \\
\hline Total SCFA $^{5}$ & $11.20 \mathrm{~b}$ & $10.80 \mathrm{~b}$ & $18.50 \mathrm{a}$ & 1.052 & $<0.001$ \\
Total PSCFA $^{6}$ & $0.09 \mathrm{c}$ & $0.24 \mathrm{~b}$ & $0.36 \mathrm{a}$ & 0.027 & $<0.001$ \\
\hline
\end{tabular}

$\mathrm{a}, \mathrm{b}-$ means within a row with no common letters differ significantly $(\mathrm{P}<0.05)$. ${ }^{1} \mathrm{SO}-100 \%$ soybean oil. ${ }^{2} \mathrm{BSFL} 50$ - a mixture of BSFL fat and SO in a 50:50 ratio. ${ }^{3}$ BSFL $100-100 \%$ BSFL fat. ${ }^{4}$ SEM - standard error of the mean. ${ }^{5} \mathrm{SCFA}$ - short-chain fatty acid. ${ }^{6} \mathrm{PSCFA}$ - putrefactive SCFA $(\mathrm{C} 4 \mathrm{i}+\mathrm{C} 5 \mathrm{i}+\mathrm{C} 5)$. Means represent 8 pooled replicates with 2 birds each $(\mathrm{n}=$ $8)$.

The volatile fatty acid concentrations in the crop digesta are shown in Table 7. BSFL100 significantly increased acetic acid $(\mathrm{P}=0.001)$ and the sum of SCFAs $(\mathrm{P}<0.001)$. The butyric acid concentration was enlarged $(\mathrm{P}=0.006)$ by the BSFL100 group, while BSFL50 had no significant effect. Both experimental treatments enhanced $(\mathrm{P}<0.001)$ fermentation of iso-valeric acid in comparison to $\mathrm{SO}$, whereas BSFL100 was characterized by the highest value. As a result, PSCFA fermentation was increased in a dose-dependent manner $(\mathrm{P}<0.001)$. In terms of the $\mathrm{SO}$ group, the propionic acid concentration was similar to the experimental treatments; however, BSFL100 resulted in intensified fermentation. There was no effect $(\mathrm{P}=0.05)$ on the concentrations of iso-butyric and valeric acids or on the SCFA profiles (Figure 1). In the jejunum segment (Table 8), only acetic acid was decreased $(\mathrm{P}=0.043)$ by the BSFL100 contrary to the control group, while the partial replacement of the SO did not differ between treatments. Additionally, the SCFA profile in the jejunum was affected $(\mathrm{P}=0.015)$ in the case of boosted fermentation of butyric acid caused by both BSFL fat inclusions (Figure 1). The volatile fatty acid concentrations in the cecal content are shown in Table 9. Iso-valeric acid was lowered $(\mathrm{P}=0.003)$ by the BSFL100 group. Moreover, BSFL50 increased $(\mathrm{P}=0.022)$ valeric acid in comparison to the control group; however, BSFL100 did not cause different effects relative to other 
treatments. Simultaneously, no differences $(\mathrm{P}=0.065)$ were observed in terms of PSCFA concentration. Within the SCFA profile, only propionic acid was decreased $(\mathrm{P}=0.039)$ by BSFL50 when the full replacement of SO was characterized by an intermediate value.

\section{The selected plasma parameters}

The selected biochemical plasma parameters are shown in Figure 2. The cholesterol concentration was re- duced $(\mathrm{P}<0.001)$ by the total replacement of $\mathrm{SO}$, while the ALT level was decreased $(\mathrm{P}=0.002)$ by both BSFL fat inclusions in the birds' diets. No significant differences were noted in terms of glucose $(P=0.063)$, triglycerides $(\mathrm{P}=0.209)$, NEFAs $(\mathrm{P}=0.118)$, total protein $(\mathrm{P}=0.066)$, albumin $(\mathrm{P}=0.113)$, or AST $(\mathrm{P}=$ $0.521)$. Similarly, select immunological traits were not affected $(\mathrm{P}>0.05)$ by the experimental factor (Figure 3 ).

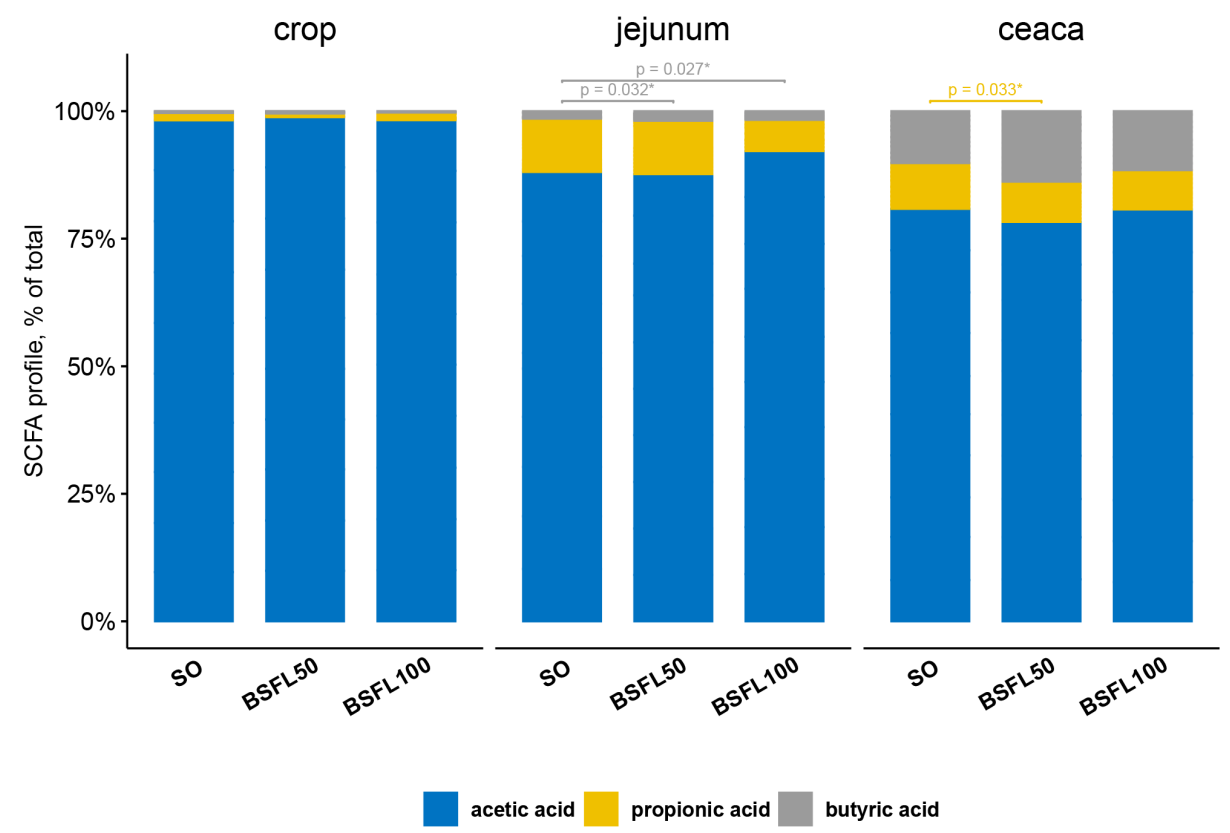

Figure 1. Short-chain fatty acid (SCFA) profile in the selected gastrointestinal tract segment contents. SO - 100\% soybean oil, BSFL50 - a mixture of BSFL fat and SO in a 50:50 ratio, BSFL100-100\% BSFL fat; asterisks indicate significant differences between treatments at the level ${ }^{*} \mathrm{P}<0.05$, while the color of asterisks the specific organic acid. The Kruskal-Wallis rank sum test for butyric acid in the jejunum was $\mathrm{P}=0.015$, while for propionic acid in the caeca was $\mathrm{P}=0.039$. The experimental unit was defined as a pooled digesta collected from two randomly chosen birds $(\mathrm{n}=8)$

Table 8. Effect of partial or total replacement of soybean oil (SO) by black soldier fly larvae (BSFL) fat on volatile fatty acids ( $\mu \mathrm{mol} / \mathrm{g}$ digesta) and short-chain fatty acid profiles in the jejunal digesta in broiler chickens

\begin{tabular}{|c|c|c|c|c|c|}
\hline & \multicolumn{3}{|c|}{ Treatment } & \multirow{2}{*}{$\mathrm{SEM}^{4}$} & \multirow{2}{*}{ P-value } \\
\hline & $\mathrm{SO}^{1}$ & BSFL $50^{2}$ & BSFL $100^{3}$ & & \\
\hline \multicolumn{6}{|c|}{ Jejunum } \\
\hline Acetic & $3.54 \mathrm{a}$ & $2.57 \mathrm{ab}$ & $2.28 \mathrm{~b}$ & 0.262 & 0.043 \\
\hline Propionic & 0.34 & 0.38 & 0.17 & 0.078 & 0.607 \\
\hline Iso-butyric & 0.01 & 0.02 & 0.01 & 0.003 & 0.176 \\
\hline Butyric & 0.04 & 0.06 & 0.04 & 0.003 & 0.085 \\
\hline Iso-valeric & 0.29 & 0.34 & 0.31 & 0.016 & 0.517 \\
\hline Valeric & 0.02 & 0.02 & 0.02 & 0.001 & 0.335 \\
\hline Total SCFA & 4.25 & 3.37 & 2.83 & 0.286 & 0.075 \\
\hline Total PSCFA ${ }^{6}$ & 0.33 & 0.38 & 0.34 & 0.017 & 0.527 \\
\hline
\end{tabular}

$\mathrm{a}, \mathrm{b}-$ means within a row with no common letters differ significantly $(\mathrm{P}<0.05) .{ }^{1} \mathrm{SO}-100 \%$ soybean oil. ${ }^{2} \mathrm{BSFL} 50-\mathrm{a}$ mixture of BSFL fat and SO in a 50:50 ratio. ${ }^{3}$ BSFL100 - 100\% BSFL fat. ${ }^{4} \mathrm{SEM}$ - standard error of the mean. ${ }^{5} \mathrm{SCFA}$ - short-chain fatty acid. ${ }^{6} \mathrm{PSCFA}-$ putrefactive SCFA (C4i+C5i+C5). Means represent 8 pooled replicates with 2 birds each $(n=8)$. 
Table 9. Effect of partial or total replacement of soybean oil (SO) by black soldier fly larvae (BSFL) fat on volatile fatty acids ( $\mu$ mol/g digesta) and short-chain fatty acid profiles in the cecal digesta in broiler chickens

\begin{tabular}{|c|c|c|c|c|c|}
\hline & \multicolumn{3}{|c|}{ Treatment } & \multirow{2}{*}{$\mathrm{SEM}^{4}$} & \multirow{2}{*}{ P-value } \\
\hline & $\mathrm{SO}^{1}$ & BSFL $502^{2}$ & BSFL100 ${ }^{3}$ & & \\
\hline \multicolumn{6}{|c|}{ Caeca } \\
\hline Acetic & 69.80 & 67.90 & 70.30 & 2.291 & 0.935 \\
\hline Propionic & 7.70 & 6.36 & 6.85 & 0.303 & 0.217 \\
\hline Iso-butyric & 0.55 & 0.92 & 0.66 & 0.078 & 0.179 \\
\hline Butyric & 8.68 & 11.71 & 10.25 & 0.580 & 0.279 \\
\hline Iso-valeric & $2.21 \mathrm{a}$ & $3.66 \mathrm{a}$ & $1.64 \mathrm{~b}$ & 0.544 & 0.003 \\
\hline Valeric & $0.78 \mathrm{~b}$ & $1.05 \mathrm{a}$ & $0.99 \mathrm{ab}$ & 0.050 & 0.022 \\
\hline Total SCFA ${ }^{5}$ & 89.70 & 91.60 & 90.70 & 2.900 & 0.818 \\
\hline Total PSCFA ${ }^{6}$ & 3.54 & 5.63 & 3.29 & 0.624 & 0.065 \\
\hline
\end{tabular}

$\mathrm{a}, \mathrm{b}-$ means within a row with no common letters differ significantly $(\mathrm{P}<0.05) .{ }^{1} \mathrm{SO}-100 \%$ soybean oil. ${ }^{2} \mathrm{BSFL} 50-\mathrm{a}$ mixture of BSFL fat and SO in a 50:50 ratio. ${ }^{3} \mathrm{BSFL} 100-100 \%$ BSFL fat. ${ }^{4} \mathrm{SEM}$ - standard error of the mean. ${ }^{5} \mathrm{SCFA}-$ short-chain fatty acid. ${ }^{6} \mathrm{PSCFA}-$ putrefactive SCFA (C4i+C5i+C5). Means represent 8 pooled replicates with 2 birds each $(n=8)$.
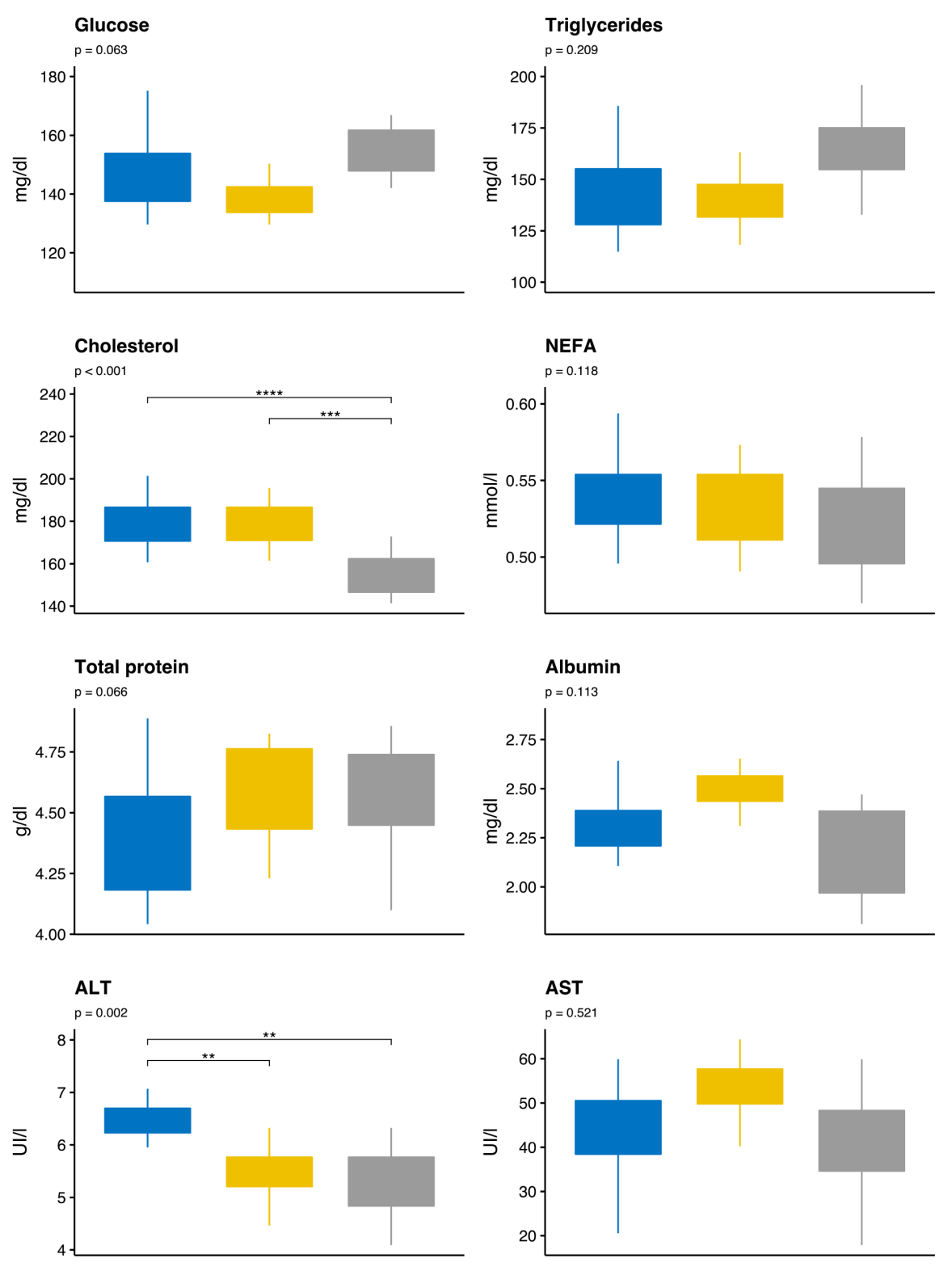

SO BSFL50 BSFL100

Figure 2. Effect of partial or total replacement of soybean oil by black soldier fly larvae fat on the selected plasma parameters in broiler chickens. SO - 100\% soybean oil, BSFL50 - a mixture of BSFL fat and SO in a 50:50 ratio, BSFL100 - 100\% BSFL fat; asterisks indicate significant differences between treatments at the level $* * \mathrm{P}<0.01, * * * \mathrm{P}<0.001, * * * * \mathrm{P}<0.0001$. Means represent 16 birds ( 1 randomly chosen chick per pen) 


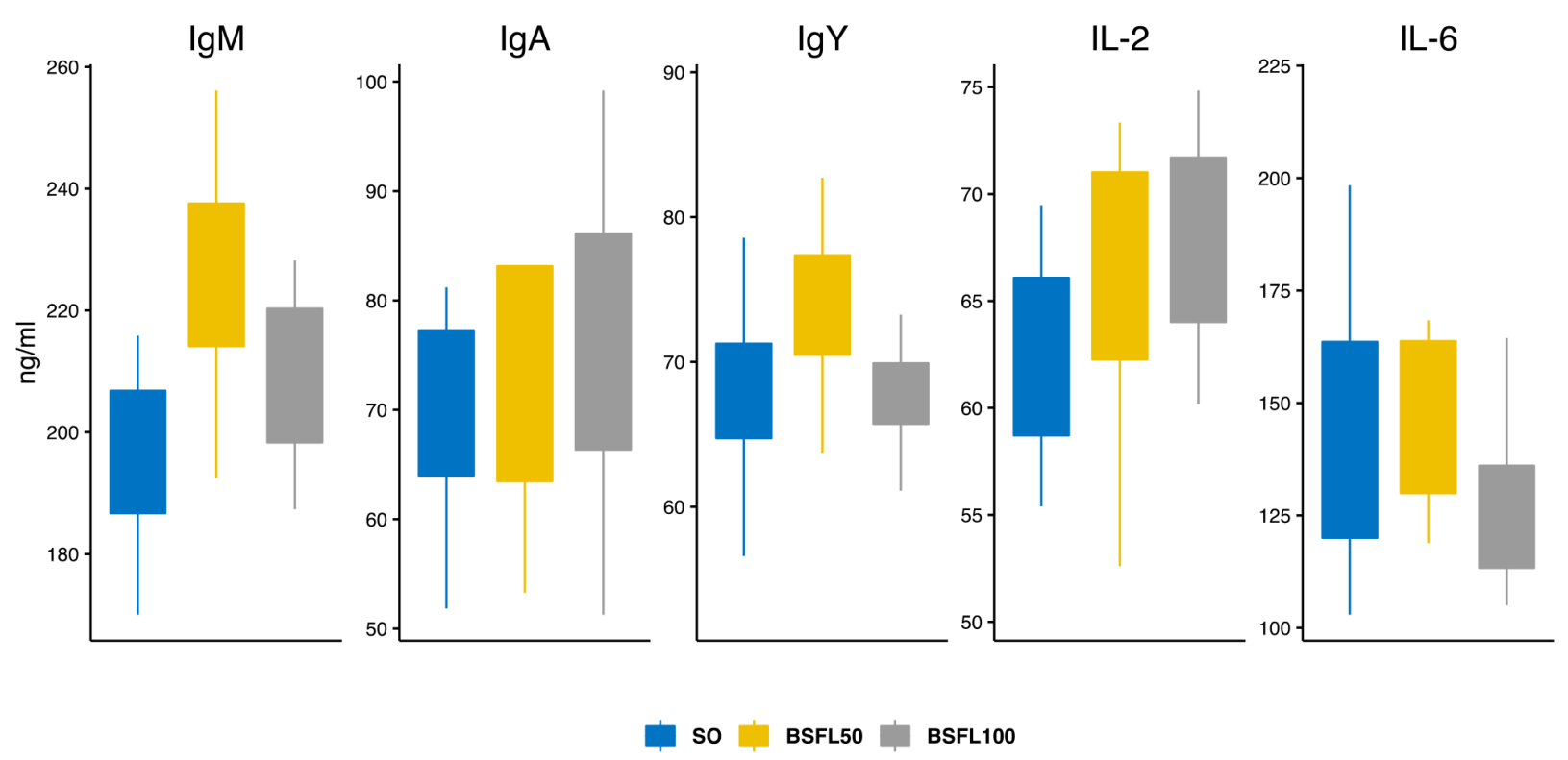

Figure 3. Effect of partial or total replacement of soybean oil by black soldier fly larvae fat on the selected immune status parameters in broiler chickens. SO - 100\% soybean oil, BSFL50 - a mixture of BSFL fat and SO in a 50:50 ratio, BSFL100 - 100\% BSFL fat; all presented data was not significantly different, i.e., $\mathrm{P}>0.05$. Means represent 16 birds ( 1 randomly chosen chick per pen)

\section{Discussion}

Insect fat as an energy source used in animal nutrition was broadly summarized by Benzertiha et al. (2020). To date, alternative and sustainable feed materials have already been implemented in poultry (e.g., broiler chickens, turkeys, and laying hens) (Cullere et al., 2019; Sypniewski et al., 2020; Kierończyk et al., 2020; Heuel et al., 2021), fish (Salmo salar, Oncorhynchus mykiss, Cyprinus carpio) (Belghit et al., 2018; Li et al., 2016; Dumas et al., 2018), pig (Heugten et al., 2019), rat (Mentang et al., 2011), and rabbit (Dalle Zotte et al., 2018; Gasco et al., 2019) diets with an analogous conclusion that it is possible to efficiently replace commonly used dietary fats. Nevertheless, in the available literature, there are limited data focused on changes in the broilers' GIT microbiota after BSFL fat administration. The beneficial effect of the high level of lauric acid (C12:0) in BSFL fat, which is the highest relative to other insect species, is frequently mentioned. In the present study, the concentration of lauric acid was $42.1 \mathrm{~g} \cdot 100 \mathrm{~g}^{-1}$ fatty acid methyl esters (FAMEs) (reported previously in Kierończyk et al., 2020). Lauric acid concentration is set at the intermediate level in comparison to previously published studies, which emphasized a range from 21 to $61 \mathrm{~g}$. $100 \mathrm{~g}^{-1}$ FAMEs (Kierończyk et al., 2020; Spranghers et al., 2017). The accumulation of lauric acid has a substantial effect on potentially pathogenic bacterial proliferation. Dabbou et al. (2020) have shown that BSFL fat (48.0 $\mathrm{g} \mathrm{C12:0} \cdot 100 \mathrm{~g}^{-1}$ FAME) denotes the strongest antimicrobial properties against Pasteurella multocida, Yers- inia enterocolitica, and Listeria monocytogenes (in vitro conditions), contrary to soybean oil, as well as Tenebrio molitor fat, which has $0.02 \mathrm{~g}$ and $0.23 \mathrm{~g} \cdot 100 \mathrm{~g}^{-1}$ FAMEs, respectively. This finding is in line with the results of Zeitz et al. (2015), who reported no impact on Lactobacillus, Bifidobacteria, Enterobacteriaceae, Campylobacter jejuni, and E. coli in the jejunal digesta of broilers fed diets where dietary fat rich in lauric acid (approximately $23 \mathrm{~g} \cdot 100 \mathrm{~g}^{-1}$ FAME) was used. It should be highlighted that lauric acid has the most effective inhibitory properties against $C$. perfringens in comparison to butyric acid, thymol, or cinnamaldehyde and may be used to prevent necrotic enteritis in poultry flocks (Timbermont et al., 2010). Even the implementation of lauric acid as a feed additive can reduce the load of Campylobacter spp. in broiler meat (Zeiger et al., 2017). Surprisingly, in the present study, the enhanced proliferation of potentially pathogenic bacteria, i.e., Bacteroides-Prevotella cluster and Enterobacteriaceae, at both levels of replacement, as well as $C$. perfringens in the case of partial substitution, was noticed. This result is even more surprising because increased levels of bacteria that produce lactic and butyric acids simultaneously significantly reduced the $\mathrm{pH}$ level in the crop to 4.48 , as confirmed by Sypniewski et al. (2020). Moreover, the highest microbial activity in the crop (BSFL100) and acetic, propionic, butyric, and iso-valeric acids, as well as total SCFA concentrations, corroborate the lower pH. Kierończyk et al. (2016) reported that one of the most important crop functions is the maintenance of the microbial barrier via, i.e., the reduction of $\mathrm{pH}$ value. In general, the Enterobacteriaceae 
and Clostridiaceae families do not tolerate $\mathrm{pH}$ values under 6.0 (Moscoviz et al., 2016). Moreover, the antimicrobial effect of the crop environment is highly dependent on ingested feed retention, as well as its moisturizing and maceration by proventriculus secreted enzymes (mainly proteolytic) transported by the antiperistalsis movement. Moreover, the availability of lauric acid at this segment could be limited, and after reaching the gizzard/duodenum, it is released after lipolysis; therefore, within the main lipid class, i.e., triacylglycerols that occur in the feed/crop, the percentage of monoacylglycerols, as well as free fatty acids, increases rapidly, especially in the duodenum (Rodriguez-Sanchez et al., 2019). Thus, the luminal lauric acid concentration may not reach the minimum inhibitory concentration and consequently does not affect the crop microbiota. Nevertheless, the obtained results stay in line with Józefiak et al. (2016 b) who reported the comparable effect of other animal origin fat, i.e., beef tallow which significantly reduces the $\mathrm{pH}$ value at this segment up to 4.45 , with the simultaneous proliferation of potentially pathogenic bacteria such as Bacteroides and butyric acid bacteria, i.e., C. leptum and C. coccoides population. Furthermore, the usage of rendered pork fat and lard resulted in a similar $\mathrm{pH}$ reduction. Additionally, the lactic acid and total organic acid concentration in the crop digesta was increased by the animal origin fat (Józefiak et al., 2014). To the best of the authors' knowledge, this is the first record of the effect of BSFL fat on the crop microbial environment, which should be continued to fully understand the abovementioned phenomenon.

To date, only Sypniewski et al. (2020) reported the positive impact of BSFL fat on the turkeys' jejunal microbiota, particularly inhibition of the Enterobacteriaceae population, as well as the total number of bacteria growth enhancement. In the present study, this effect was not noticeable. Furthermore, the bacterial activity was decreased in terms of acetic acid during BSFL fat addition to broiler diets, while the SCFA concentration was not affected. However, a positive reduction in the $\mathrm{pH}$ value in the jejunum was observed, contrary to the analogous segment in turkeys (Sypniewski et al., 2020). This finding is in agreement with the findings of Kim et al. (2020 a), who reported the lack of impact of BSFL fat application to birds' diets on $C$. perfringens counts, as well as SCFA total concentration in the small intestine. Thus, the increased butyric acid in the SCFA profile with BSFL fat addition is not connected to butyric acid fermentative bacterial proliferation, such as Clostridiacae members, as well as an absolute butyric acid concentration at this segment.

The most intensive microbiota changes were observed for the cecal content in the scope of partial substitution of SO, while total replacement showed similar effects as the control group. The positive effect of BSFL fat on select cecal microbiota populations, i.e., BacteroidesPrevotella cluster, was recorded in turkeys fed BSFL fat (Kierończyk et al., 2022). In the available literature, there is a lack of information regarding the GIT microbiota changes in this segment during BSFL fat application to the birds' diets. Only indirect effects of microbial activity, i.e., SCFA concentrations, shown by Kim et al. (2020 b) and Kim et al. (2020 a), demonstrated no significant changes or small effects on the relative value of total volatile fatty acids, i.e., acetate level reduction and butyrate production, respectively. The favorable microbial results in terms of cecal content during the partial substitution of SO are connected with the simultaneous effect of lauric acid from BSFL fat, as well as the dilution of saturated fatty acids (SFAs) by SO in the mixture enriched by the omega-3 polyunsaturated fatty acids. It is well known that dietary fats of animal origin, such as beef tallow or pig lard, are rich in SFAs. Furthermore, SFAs are considered proinflammatory factors that promote lipopolysaccharideproducing bacteria in the GIT (Xiang et al., 2019). These dietary energy sources induce an adverse effect on the birds' cecal microbiota by increasing the proliferation of potentially pathogenic bacteria, e.g., C. perfringens, and lactic acid bacteria, which should be a minority in this segment, as well as reducing counts of commensal bacteria, such as C. coccoides (Józefiak et al., 2016 b). Moreover, the combination of animal-origin fat and plant oils is commonly used in practical poultry nutrition to improve the final SCFA profile in the diet (Poorghasemi et al., 2013). Simultaneously, the improvement of omega-3 FAs concentration in the mixture may have a positive effect on the inhibition of potentially pathogenic bacteria in the GIT (Neijat et al., 2020; Costantini et al., 2017). For the abovementioned reasons, it can be assumed that not only the presence of lauric acid but also the ratio between SFAs and UFAs, and the omega-3 FAs level should be considered antimicrobial factors during BSFL fat administration in poultry diets.

Generally, in previously published studies, only minor changes in blood biochemistry traits were observed, including increased cholesterol and NEFA levels in the scope of BSFL fat administration to poultry diets (Sypniewski et al., 2020). However, no impact on select blood parameters was observed even more frequently (Schiavone et al., 2017, 2018; Kim et al., 2020 a; Dabbou et al., 2021). Kim et al. (2020 b) reported no effect on the serum characteristics of 15-d-old birds, while 30-d-old chickens were characterized by reduced blood cholesterol levels due to BSFL fat in comparison to coconut oil. In the present study, the cholesterol level was positively decreased in the group where BSFL fat was used as a full substituent. It is well-known that cholesterol is involved in the bile salts synthesis which improves fat digestibility. Contrary to the plant origin dietary fats, beef tallow increases the blood cholesterol level which may be parallel to the bile salts extraction in the duodenum to enhance the fat utilization especially those containing saturated long-chain fatty acids (Alzawqari et al., 2011). As was mentioned previously by Kierończyk et al. (2020) the apparent digestibility coefficient of fat was not affected by the various BSFL inclusion, thus the lowered cholesterol concentration may be connected to efficient fat utiliza- 
tion and lack of necessity of additional bile salt synthesis, consequently positive limiting of energy expenditure. Additionally, the lowering of cholesterol level, as well as ALT concentration, can be connected to a beneficial effect on liver health, as well (Lin et al., 2021).

\section{Conclusions}

The present study revealed that BSFL fat inclusion in broiler diets led to adverse microbiota shifts in the chickens' crop, probably as a result of insufficient release of lauric acid at this stage of digestion. Nevertheless, the neutral effect of BSFL fat administration on the broiler chicken jejunal microbiota and its activity or positive influence on select bacterial populations in the cecal content were noted. However, the partial substitution of soybean oil by BSFL fat is characterized by the greatest suppression of potentially pathogenic populations, probably due to SFA dilution and increase of omega-3 polyunsaturated fatty acids. Furthermore, no detrimental effect of BSFL fat on the selected blood parameters or immune traits was observed. Nevertheless, the beneficial effect on the liver health of birds was observed via cholesterol level reduction, as well as a decreased concentration of ALT. Thus, soybean oil as a commonly used energy source can be efficiently replaced by BSFL fat in terms of the physiological and immunological response of birds, nevertheless, due to the observed adverse effect on the crop microbial populations, there is a need to evaluate the possible improvement of the lauric acid bioavailability in the upper gastrointestinal segments.

\section{References}

Alzawqari M., Moghaddam H.N., Kermanshahi H., Raji A.R. (2011). The effect of desiccated ox bile supplementation on performance, fat digestibility, gut morphology and blood chemistry of broiler chickens fed tallow diets. J. Appl. Anim Res., 39: 169-174.

Aviagen (2018). Ross Broiler Management Handbook. Aviagen Limited Newbridge Midlothian EH28 8SZ, Scotland, UK.

Baltić B., Starčević M., Đorđević J., Mrdović B., Marković R. (2017) Importance of medium chain fatty acids in animal nutrition. In: IOP Conference Series: Earth Env. Sci., IOP Publishing, 85: 12048.

Baltić B., Ćirić J., Šefer D., Radovanović A., Đorđević J., Glišić M., Bošković M., Baltić M.Ž., Đorđević V., Marković R. (2018). Effect of dietary supplementation with medium chain fatty acids on growth performance, intestinal histomorphology, lipid profile and intestinal microflora of broiler chickens. S. Afr. J. Anim. Sci., 48: 885-896.

Barragan-Fonseca K.B., Gort G., Dicke M., van Loon J.J.A. (2019). Effects of dietary protein and carbohydrate on life-history traits and body protein and fat contents of the black soldier fly Hermetia illucens. Physiol. Entomol., 44: 148-159.

Belghit I., Liland N.S., Waagbø R., Biancarosa I., Pelusio N., Li Y., Krogdahl Å., Lock E-J. (2018). Potential of insect-based diets for Atlantic salmon (Salmo salar). Aquaculture, 491: 72-81.

Benzertiha A., Kierończyk B., Rawski M., Kołodziejski P., Bryszak M., Józefiak D. (2019). Insect oil as an alternative to palm oil and poultry fat in broiler chicken nutrition. Animals, 9: 116.

Benzertiha A., Kierończyk B., Rawski M., Mikołajczak Z., Urbański A., Nogowski L., Józefiak D. (2020). Insect fat in animal nutrition: a review. Ann. Anim. Sci., 20: 1217-1240.
Caligiani A., Marseglia A., Sorci A., Bonzanini F., Lolli V., Maistrello L., Sforza S. (2019). Influence of the killing method of the black soldier fly on its lipid composition. Food Res. Int., 116: 276-282.

Canibe N., Højberg O., Badsberg J. H., Jensen B.B. (2007). Effect of feeding fermented liquid feed and fermented grain on gastrointestinal ecology and growth performance in piglets. J. Anim. Sci., 85: 2959-2971.

Costantini L., Molinari R., Farinon B., Merendino N. (2017). Impact of omega-3 fatty acids on the gut microbiota. Int. J. Mol. Sci., 18: 2645 .

Cullere M., Schiavone A., Dabbou S., Gasco L., Dalle Zotte A. (2019). Meat quality and sensory traits of finisher broiler chickens fed with black soldier fly (Hermetia illucens L.) larvae fat as alternative fat source. Animals, 9: 1-15.

Dabbou S., Ferrocino I., Gasco L., Schiavone A., Trocino A., Xiccato G., Lajusticia A.C.B., Maione S., Soglia D., Biasato I. (2020). Antimicrobial effects of black soldier fly and yellow mealworm fats and their impact on gut microbiota of growing rabbits. Animals, 10: 1292 .

Dabbou S., Lauwaerts A., Ferrocino I., Biasato I., Sirri F., Zampiga M., Bergagna S., Pagliasso G., Gariglio M., Colombino E. (2021). Modified black soldier fly larva fat in broiler diet: effects on performance, carcass traits, blood parameters, histomorphological features and gut microbiota. Animals, 11: 1837.

Dalle Zotte A., Cullere M., Martins C., Alves S.P., Freire J.P.B., Falcão-e-Cunha L., Bessa R.J.B. (2018). Incorporation of black soldier fly (Hermetia illucens L.) larvae fat or extruded linseed in diets of growing rabbits and their effects on meat quality traits including detailed fatty acid composition. Meat Sci., 146: 50-58.

Dumas A., Raggi T., Barkhouse J., Lewis E., Weltzien E. (2018). The oil fraction and partially defatted meal of black soldier fly larvae (Hermetia illucens) affect differently growth performance, feed efficiency, nutrient deposition, blood glucose and lipid digestibility of rainbow trout (Oncorhynchus mykiss). Aquaculture, 492: 24-34.

Ewald N., Vidakovic A., Langeland M., Kiessling A., Sampels S., Lalander C. (2020). Fatty acid composition of black soldier fly larvae (Hermetia illucens) - possibilities and limitations for modification through diet. Waste Manage, 102: 40-47.

Fallani M., Rigottier-Gois L., Aguilera M., Bridonneau C., Collignon A., Edwards C.A., Corthier G., Doré J. (2006). Clostridium difficile and Clostridium perfringens species detected in infant faecal microbiota using 16S rRNA targeted probes. J. Microbiol. Meth., 67: $150-161$.

Feng W., Xiong H., Wang W., Duan X., Yang T., Wu C., Yang F., Xiong J., Wang T., Wang C. (2019). Energy consumption analysis of lipid extraction from black soldier fly biomass. Energy, 185: 1076-1085.

Franks A.H., Harmsen H.J.M., Raangs G.C., Jansen G.J., Schut F., Welling G.W. (1998). Variations of bacterial populations in human feces measured by fluorescent in situ hybridization with group-specific 16S rRNA-targeted oligonucleotide probes. Appl. Environ. Microbiol., 64: 3336-3345.

Gasco L., Dabbou S., Gai F., Brugiapaglia A., Schiavone A., Birolo M., Xiccato G., Trocino A. (2019). Quality and consumer acceptance of meat from rabbits fed diets in which soybean oil is replaced with black soldier fly and yellow mealworm fats. Animals, 9: 629.

Hejdysz M., Kaczmarek S., Józefiak D., Jamroz D., Rutkowski A. (2018). Effect of different medium chain fatty acids, calcium butyrate, and salinomycin on performance, nutrient utilization, and fermentation products in gastrointestinal tracts of broiler chickens. J. Anim. Plant Sci., 28: 377-387.

Heuel M., Sandrock C., Leiber F., Mathys A., Gold M., Zurbrügg C., Gangnat I.D.M., Kreuzer M., Terranova M. (2021). Black soldier fly larvae meal and fat can completely replace soybean cake and oil in diets for laying hens. Poultry Sci., 100: 101034.

Heugten E. van, Martinez G., McComb A., Koutsos E. (2019). 285 Black soldier fly (Hermetia illucens) larvae oil improves growth performance of nursery pigs. J. Anim. Sci., 97(Supplement 3): 118 . 
Jackowski J., Hurej M., Rój E., Poplonski J., Kosny L., Huszcza E. (2015). Antifeedant activity of xanthohumol and supercritical carbon dioxide extract of spent hops against stored product pests. B. Entomol. Res., 105: 456.

Józefiak D., Kierończyk B., Juśkiewicz J., Zduńczyk Z., Rawski M., Długosz J., Sip A., Højberg O. (2013). Dietary nisin modulates the gastrointestinal microbial ecology and enhances growth performance of the broiler chickens. PLoS One, 8(12): 1-11.

Józefiak D., Kierończyk B., Rawski M., Hejdysz M., Rutkowski A., Engberg R.M., Højberg O. (2014). Clostridium perfringens challenge and dietary fat type affect broiler chicken performance and fermentation in the gastrointestinal tract. Animal, 8: 912-922.

Józefiak D., Józefiak A., Kierończyk B., Rawski M., Świątkiewicz S., Długosz J., Engberg R.M. (2016 a). Insects - a natural nutrient source for poultry - a review. Ann. Anim. Sci., 16: 297-313.

Józefiak D., Świątkiewicz S., Kierończyk B., Rawski M., Długosz J., Engberg R.M., Højberg O. (2016 b). Clostridium perfringens challenge and dietary fat type modifies performance, microbiota composition and histomorphology of the broiler chicken gastrointestinal tract. Eur. Poultry Sci., 80.

Kierończyk B., Rawski M., Długosz J., Świątkiewicz S., Józefiak D. (2016). Avian crop function - a review. Ann. Anim. Sci., 16: 653-678.

Kierończyk B., Sassek M., Pruszynska-Oszmalek E., Kolodziejski P., Rawski M., Świątkiewicz S., Józefiak D. (2017). The physiological response of broiler chickens to the dietary supplementation of the bacteriocin nisin and ionophore coccidiostats. Poultry Sci., 96: 4026-4037.

Kierończyk B., Rawski M., Józefiak A., Mazurkiewicz J., Świątkiewicz S., Siwek M., Bednarczyk M., Szumacher-Strabel M., Cieślak A., Benzertiha A., Józefiak D. (2018). Effects of replacing soybean oil with selected insect fats on broilers. Anim. Feed Sci. Tech., 240: $170-183$.

Kierończyk B., Sypniewski J., Rawski M., Czekała W., Świątkiewicz S., Józefiak D. (2020). From waste to sustainable feed material: the effect of Hermetia illucens oil on the growth performance, nutrient digestibility, and gastrointestinal tract morphometry of broiler chickens. Ann. Anim. Sci., 20: 157-177.

Kierończyk B., Sypniewski J., Mikołajczak Z., Rawski M., Pruszyńska-Oszmałek E., Sassek M., Kołodziejski P., Józefiak D. (2022). Replacement of soybean oil with cold-extracted fat from Hermetia illucens in young turkey diets: Effects on performance, nutrient digestibility, selected organ measurements, meat and liver tissue traits, intestinal microbiota modulation, and physiological and immunological status. Anim. Feed Tech., 286: 115210.

Kim S.A., Rhee M.S. (2016). Highly enhanced bactericidal effects of medium chain fatty acids (caprylic, capric, and lauric acid) combined with edible plant essential oils (carvacrol, eugenol, $\beta$-resorcylic acid, trans-cinnamaldehyde, thymol, and vanillin) against Escherichia coli O15. Food Control, 60: 447-454.

Kim B., Bang H.T., Jeong J.Y., Kim M., Kim K.H., Chun J.L., Ji S.Y. $(2020$ a). Effects of dietary supplementation of black soldier fly (Hermetia illucens) larvae oil on broiler health. J. Poultry Sci., 200070.

Kim Y.B., Kim D.H., Jeong S.B., Lee J.W., Kim T.H., Lee H.G., Lee K.W. (2020 b). Black soldier fly larvae oil as an alternative fat source in broiler nutrition. Poultry Sci., 99: 3133-3143.

Li S., Ji H., Zhang B., Tian J., Zhou J., Yu H. (2016). Influence of black soldier fly (Hermetia illucens) larvae oil on growth performance, body composition, tissue fatty acid composition and lipid deposition in juvenile Jian carp (Cyprinus carpio var. Jian). Aquaculture, 465: 43-52.

Lieberman S., Enig M.G., Preuss H.G. (2006). A review of monolaurin and lauric acid: natural virucidal and bactericidal agents. Altern. Complem. Ther., 12: 310-314.

Lin C.-W., Huang T.-W., Peng Y.-J., Lin Y.-Y., Mersmann H.J., Ding S.-T. (2021). A novel chicken model of fatty liver disease induced by high cholesterol and low choline diets. Poultry Sci., 100: 100869.

Mai H.C., Dao N.D., Lam T.D., Nguyen B.V., Nguyen D.C., Bach L.G. (2019). Purification process, physicochemical properties, and fatty acid composition of black soldier fly (Hermetia illucens Linnaeus) larvae oil. J. Am. Oil Chem. Soc., 96: 1303-1311.

Mailund T. (2019). Manipulating data frames: dplyr. In: R Data Science Quick Reference, 109-60. Springer.

Manz W., Szewzyk U., Ericsson P., Amann R., Schleifer K.H., Stenström T.A. (1993). In situ identification of bacteria in drinking water and adjoining biofilms by hybridization with $16 \mathrm{~S}$ and $23 \mathrm{~S}$ rRNA-directed fluorescent oligonucleotide probes. Appl. Environ. Microb., 59: 2293-2298.

Melis R., Braca A., Mulas G., Sanna R., Spada S., Serra G., Fadda M.L., Roggio T., Uzzau S., Anedda R. (2018). Effect of freezing and drying processes on the molecular traits of edible yellow mealworm. Innov. Food Sci. Emerg., 48: 138-149.

Mendiburu F.D., Simon R. (2015). Agricolae - ten years of an open source statistical tool for experiments in breeding, agriculture and biology. Peer J. Pre Prints, 3:e1404v1.

Mentang F., Maita M., Ushio H., Ohshima T. (2011). Efficacy of silkworm (Bombyx mori L.) chrysalis oil as a lipid source in adult wistar rats. Food Chem., 127: 899-904.

Moscoviz R., Trably E., Bernet N. (2016). Consistent 1,3-propanediol production from glycerol in mixed culture fermentation over a wide range of $\mathrm{pH}$. Biotech. Biofuels, 9: 32 .

Neijat M., Habtewold J., Li S., Jing M., House J.D. (2020). Effect of dietary $n-3$ polyunsaturated fatty acids on the composition of cecal microbiome of Lohmann hens. Prostag. Leukotr. Ess., 162: 102182.

Ogle D.H. (2016). Introductory fisheries analyses with R. Vol. 32. CRC Press.

Poorghasemi M., Alireza S., Qotbi A.A.A., Laudadio V., Tufarelli V. (2013). Influence of dietary fat source on growth performance responses and carcass traits of broiler chicks. Asian Austral. J. Anim., 26: 705.

Purschke B., Stegmann T., Schreiner M., Jäger H. (2017). Pilot-scale supercritical $\mathrm{CO}_{2}$ extraction of edible insect oil from Tenebrio molitor L. larvae - influence of extraction conditions on kinetics, defatting performance and compositional properties. Eur. J. Lipid Sci. Tech., 119: 1600134.

Rasco D. (2020). An R Companion for Applied Statistics I: Basic Bivariate Techniques. SAGE Publications, Thousand Oaks, CA, USA.

Rawski M., Kierończyk B., Długosz J., Świątkiewicz S., Józefiak D. (2016). Dietary probiotics affect gastrointestinal microbiota, histological structure and shell mineralization in turtles. PLoS One, 11(2): $\mathrm{e} 0147859$

Revelle W. (2017). An introduction to the psych package: Part I: Data entry and data description. Retrieved from: https://personalityproject.org/r/psych/intro.pdf.

Rodriguez-Sanchez R., Tres A., Sala R., Guardiola F., Barroeta A.C. (2019). Evolution of lipid classes and fatty acid digestibility along the gastrointestinal tract of broiler chickens fed different fat sources at different ages. Poultry Sci., 98: 1341-1353.

Salzman N.H., de Jong H., Paterson Y., Harmsen H.J.M., Welling G.W., Bos N.A. (2002). Analysis of 16S libraries of mouse gastrointestinal microflora reveals a large new group of mouse intestinal bacteria. Microbiology, 148: 3651-3660.

Schiavone A., Cullere M., De Marco M., Meneguz M., Biasato I., Bergagna S., Dezzutto D., Gai F., Dabbou S., Gasco L. (2017). Partial or total replacement of soybean oil by black soldier fly larvae (Hermetia illucens L.) fat in broiler diets: effect on growth performances, feed choice, blood traits, carcass characteristics and meat quality. Ital. J. Anim. Sci., 16: 93-100.

Schiavone A., Dabbou S., De Marco M., Cullere M., Biasato I., Biasibetti E., Capucchio M.T., Bergagna S., Dezzutto D., Meneguz M., Gai F., Dalle Zotte A., Gasco L. (2018). Black soldier fly larva fat inclusion in finisher broiler chicken diet as an alternative fat source. Animal, 12: 2032-2039.

Schumacker R., Tomek S. (2013). R Fundamentals. In: Understanding statistics using R, Schumacker R., Tomek S. (eds). Springer New York, USA, pp. 1-10.

Sghir A., Gramet G., Suau A., Rochet V., Pochart P., Dore J. (2000). Quantification of bacterial groups within human fecal flora by oligonucleotide probe hybridization. Appl. Environ. Microbiol., 66: 2263-2266. 
Spranghers T., Ottoboni M., Klootwijk C., Ovyn A., Deboosere S., De Meulenaer B., Michiels J., Eeckhout M., De Clercq P., De Smet S. (2017). Nutritional composition of black soldier fly (Hermetia illucens) prepupae reared on different organic waste substrates. J. Sci. Food Agr., 97: 2594-2600.

Sypniewski J., Kierończyk B., Benzertiha A., Mikołajczak Z., Pruszyńska-Oszmałek E., Kołodziejski P., Sassek M., Rawski M., Czekała W., Józefiak D. (2020). Replacement of soybean oil by Hermetia illucens fat in turkey nutrition: effect on performance, digestibility, microbial community, immune and physiological status and final product quality. Brit. Poultry Sci., 61: 294-302.

Tancharoenrat P., Ravindran V., Zaefarian F., Ravindran G. (2013). Influence of age on the apparent metabolisable energy and total tract apparent fat digestibility of different fat sources for broiler chickens. Anim. Feed Sci. Tech., 186: 186-192.

Timbermont L., Lanckriet A., Dewulf J., Nollet N., Schwarzer K., Haesebrouck F., Ducatelle R., Van Immerseel F. (2010). Control of Clostridium perfringens-induced necrotic enteritis in broilers by target-released butyric acid, fatty acids and essential oils. Avian Pathol., 39: 117-121.
Weththasinghe P., Hansen J.Ø., Nøkland D., Lagos L., Rawski M., Øverland M. (2021). Full-Fat black soldier fly larvae (Hermetia illucens) meal and paste in extruded diets for Atlantic salmon (Salmo salar): effect on physical pellet quality, nutrient digestibility, nutrient utilization and growth performances. Aquaculture, 530: 735785 .

Xiang M.S.W., Tan J.K., Macia L. (2019). Fatty acids, gut bacteria, and immune cell function. Mol. Nutr. Fats, 151-164.

Zeiger K., Popp J., Becker A., Hankel J., Visscher C., Klein G., Meemken D. (2017). Lauric acid as feed additive - an approach to reducing Campylobacter spp. in broiler meat. PLoS One, 12(4): $\mathrm{e} 0175693$.

Zeitz J.O., Fennhoff J., Kluge H., Stangl G.I., Eder K. (2015). Effects of dietary fats rich in lauric and myristic acid on performance, intestinal morphology, gut microbes, and meat quality in broilers. Poultry Sci., 94: 2404-2413.

Received: 4 V 2021

Accepted: 26 VIII 2021 